\title{
Friction Resistance of Refined, Bleached and Deodorized (RBD) Palm Olein Using Modified Pin-on-disk Tribotester
}

\author{
M. I. Izhan ${ }^{a^{*}}$, A. K. Mohammed Rafiq ${ }^{b}$, S. Syahrullail ${ }^{c}$ \\ ${ }^{a}$ School of Graduates Studies, Universiti Teknologi Malaysia, 81310 UTM Johor Bahru, Johor, Malaysia \\ ${ }^{b}$ Faculty of Biomedical Engineering \& Health Science, Universiti Teknologi Malaysia, 81310 UTM Johor Bahru, Johor, Malaysia \\ ${ }^{c}$ Faculty of Mechanical Engineering, Universiti Teknologi Malaysia, 81310 UTM Johor Bahru, Johor, Malaysia
}

*Corresponding author: m_izhan16@yahoo.com

\section{Article history}

Received :26 March 2012

Received in revised form :15

September 2012

Accepted :5 December 2012

Graphical abstract

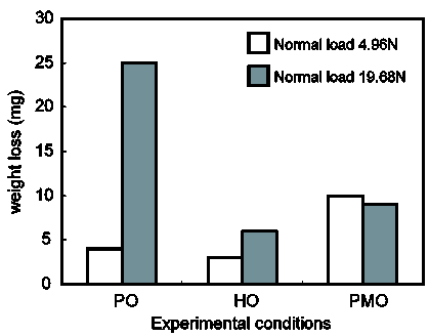

\begin{abstract}
A friction resistance of refined, bleached and deodorized (RBD) palm olein was evaluated using a modified pin-on-disk tribotester. RBD palm olein was selected due to its superior tribological properties and large production in Malaysia. In this research, $5 \mathrm{ml}$ of RBD palm olein was applied on the rotating grooved-disk. The flat-ended pin was used as a specimen. The material was titanium for both pin and disk. The normal loads applied are $4.96 \mathrm{~N}$ and $19.68 \mathrm{~N}$. The experiments were run for one hour. The wear rate of the pin and friction coefficient was calculated. Same experiments were conducted using commercial hydraulic oil and additive-free paraffinic mineral oil. The results were compared with RBD palm olein. The friction coefficient with the lubrication of RBD palm olein was the lowest for $4.96 \mathrm{~N}$ and $19.68 \mathrm{~N}$ under normal load conditions. Wear rate obtained by RBD palm olein at normal load $4.96 \mathrm{~N}$ was the lowest; however, RBD palm olein showed a high wear rate when high normal load $(19.68 \mathrm{~N})$ was applied.

Keywords: Pin-on-disk; palm oil; palm olein; wear; friction coefficient

Abstrak

Daya geseran untuk minyak sawit olein yang ditapis, diluntur dan dinyahbau (RBD olein) telah dinilai dengan menggunakan alat tribotester pin-atas-cakera. RBD olein telah dipilih kerana sifat-sifat unggul tribologi dan pengeluarannya yang besar di Malaysia. Dalam kajian ini, 5ml minyak RBD olein telah digunakan pada cakera beralur. Pin yang mempunyai hujung rata telah digunakan sebagai bahan ujikaji. Cakera dan pin diperbuat daripada titanium alloy. Beban normal yang dikenakan pada pin ialah $4.96 \mathrm{~N}$ dan 19.68N. Ujikaji telah dijalankan selama satu jam. Kadar haus pin dan pekali geseran telah dikira. Ujikaji yang sama telah dijalankan dengan menggunakan minyak hidraulik komersial dan minyak mineral jenis parafinik yang tidak mengandungi bahan tambah. Pekali geseran yang dihasilkan oleh pelinciran minyak sawit RBD olein adalah terendah berbanding minyak mineral parafinik pada kedua-dua jenis beban $(4.96 \mathrm{~N}$ dan $19.68 \mathrm{~N})$. Bagaimanapun, minyak sawit RBD olein menunjukkan kadar haus yang tinggi berbanding minyak mineral parafinik pada beban normal $19.68 \mathrm{~N}$.
\end{abstract}

Kata kunci: Pin-atas-cakera; minyak sawit; palm olein; haus; pekali geseran

(C) 2012 Penerbit UTM Press. All rights reserved.

\subsection{INTRODUCTION}

Despite the advancement of technology, the wear characteristic complications of operating machines and engines are still the main problems faced by the industries applying machineries, and it is a necessity to overcome by searching more alternatives of designing a product that helps prolong wear. As the engines and machines are continuously running and the operating condition becomes more severe, more problems are faced by the mating components due to the damage mainly caused by wear and frictional force. In machining and operating engines, the effects of wear and friction are a natural phenomenon which could lead to failure. It is widely accepted that wear and friction primarily change with load, speed (Chowdhury et al., 2011), temperature (Nofal and Hussein, 2011), surface roughness (Terumasa et al., 2000; Sedlacek et al., 2009), type of material or mating component (Bressan et al., 2008) and the environment. The study in understanding the wear mechanism by utilizing different parameters plays a very important role in identifying new findings and solutions for these particular problems.

In order to reduce undesirable effects of wear and frictional force, lubricant is a preeminent alternative applied to mating components and creates a lubricant film to preserve the direct contact of two surfaces. As reported by Delgado et al. (2010), the 
conventional lubricant, the petroleum-based lubricant, being widely used as lubricating oil, causes ecological pollution. It has been observed that nearly 12 million tons of lubricant wastes have been disposed into the environment. In awareness towards environmental and health issues, global industries have made efforts to eliminate or reduce the consumption of conventional petroleum lubricants. Vegetable oils are potential as the best substitute and developed for industrial applications. Husnawan and his colleague (2007) found that the presence of vegetable oils as lubricants is attributed to the decrease of mineral oil application in the industry due to its biodegrade ability. Vegetable oils are not a new discovery as lubricant and their advantages have already widely known, even since the Ancient Egypt, where they used vegetable oils in the construction of large monuments, as reported by Nosonovsky (2007). Vegetable oils are readily biodegradable and less costly than mineral-based oils and show quite acceptable and reliable potential as lubricants. The advantages of choosing vegetable oils are of their environmentally friendly characteristic, biodegradability, less toxic and low cost compared to mineral based oil. Masjuki et al. (1999) and Maleque et al. (2000) explained that vegetable oils compositions consist of triacylglycerides, which have molecular structures of long chain fatty acids, which have better fundamental boundary lubricant properties and can create high strength lubricant film. In addition, according to Lawal et al. (2012) and Bowder and Tabor (2001), a thin film or monolayer phenomenon; also known as soap film, interacts strongly with two contact surfaces attributed to the reduction of wear and friction.

One of the potential vegetable oils as lubricant in the industries, especially in engines and machines, is palm oil. According to Mekhilef et al. (2011), in the current world palm oil production, Malaysia is the second largest producer. In the early 20th century, Malaysian Palm Oil Board (MPOB) has productively produced palm oil methyl ester from crude palm oil by using transesterification method, as explained by Maleque et al., (2000). Palm oil, or its botanical classification as Elaeis guineensis, has been widely applied, such as fuels for diesel engines (Pascal and Mohand, (2011)), hydraulic fluid (Wan Nik et al., 2005), and lubricants (Syahrullail et al., 2011). It has also been confirmed to emit less carbon dioxide emission into the atmosphere that can cause greenhouse effect.

To study the wear of the materials, researchers simulate the process of wear in a controlled manner and study the effect on different samples, using the same test conditions by performing a pin-on-disk test. The wear test configuration is simulated by using a flat-end pin against a flat-grooved rotating disk. As concluded by Garcia-Prieto et al. (2004), a flat end has some natural advantages: it easier to machine and easier to coat if a wear test of coating is required. For this reason, flat-end pins are used in most of the pin-on-disk tests. In this study, the volume was estimated for use, to accurately calculate the wear rate of material. Palm oil was used as the main lubricating oil in studying wear characteristic. Additive-free paraffinic mineral and commercial hydraulic oil were used as comparative lubricants to palm oil. The experiments were run in a duration of one hour at a constant speed of $0.5 \mathrm{~m} / \mathrm{s}$, following the ASTM G99.

\subsection{EXPERIMENTAL METHOD}

\subsection{Apparatus}

In the present investigation, the pin-on-disk had been used to study both wear and coefficient of friction. The pin-on-disk test is commonly used in a comparative test in which the controlled wear is performed on the samples to study. The volume loss allows the calculation of the wear rate of the material. In this method, a pin is clamped firmly against a rotating disk linked to a certain dead weight with a beam and two pulleys.

In this experiment, the test lubricant was not pumped and flowed through out the experiment time. $5 \mathrm{ml}$ of test lubricant was used. To make sure the test lubricant did not flow out due to the centrifugal force while the disk rotated, a groove with $10 \mathrm{~mm}$ width and $5 \mathrm{~mm}$ depth was provided in the rotating disk. The flatend pin surface, which was used as a specimen was touched onto the horizontal surface of the groove at the beginning of the experiment.

A linear voltage differential transformer (LVDT) sensor was used to read the wear rate. The grooved-disk is cleaned before experiment using acetone. The surface roughness was recorded according to the parameter set up by researcher. Figure 1 shows the arrangement of the grooved-disk and the flat-end pin.

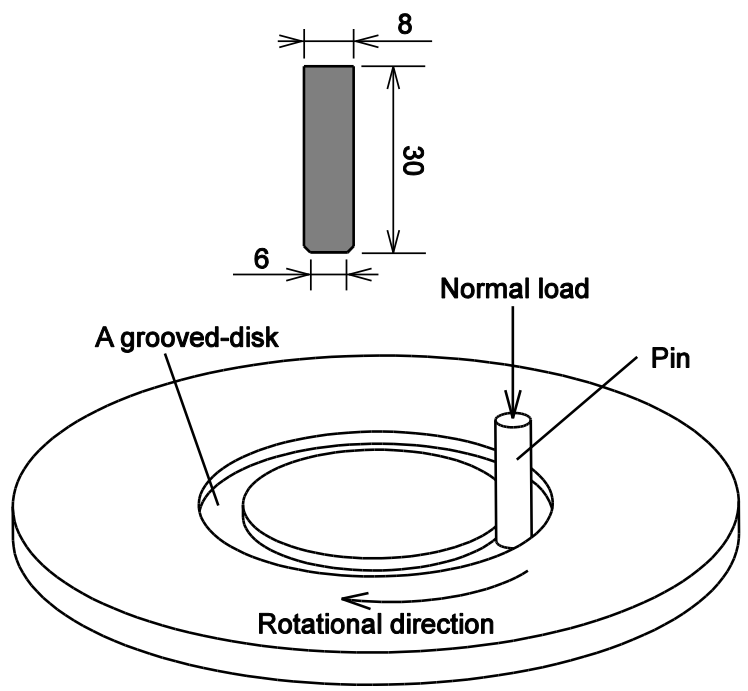

Figure 1 The grooved-disk and flat-ended pin specimen

\subsection{Specimen Material and Lubricants}

The grooved-disk and the flat-end pin were made from titanium. Pin samples were prepared as $8 \mathrm{~mm}$ in diameter (with $1 \mathrm{~mm}$ taper cut at the experimental surface) and $30 \mathrm{~mm}$ in length, as shown in Figure 1. The density of titanium was $4.54 \mathrm{~g} / \mathrm{cm}^{3}$. After the completion of each test, a sandpaper with the abrasive surface of $1000 \mu \mathrm{m}$ was used to grind the surface so that the surface finished was between specifications. The surface roughness of the disk was measured using a surface roughness profiler which consisted of a stylus detector to determine the pattern of the disk and pin surface. RBD palm olein, commercial hydraulic oil and additivefree paraffinic mineral oil were used as the test lubricating oils, with the same volume of $5 \mathrm{ml}$. The test lubricants were dripped onto the specific location before the experiment, as shown in Figure 1 . The specific density and dynamic viscosity of the three types of lubricants were measured beforehand using a viscometer at the temperature between $40^{\circ} \mathrm{C}$ and $100^{\circ} \mathrm{C}$.

\subsection{Experimental Setup}

The experiments were conducted according to ASTM G99. Both the surfaces of the pins and disk were made parallel to ensure their maximum contact. The principle of sliding was using a cantilever loaded pin against the horizontal rotating grooved disk in a lubricant oil bath. All the tests were carried out at room 
temperature, $22 \pm 2{ }^{\circ} \mathrm{C}$. In this experiment, $4.96 \mathrm{~N}$ and $19.86 \mathrm{~N}$ of the normal loads were applied, and the rotating time was one hour. The masses of the pins were measured before and after each test, and the weight losses were recorded. The surface finishes of the pins were measured before and after the experiment.

\subsection{Wear and Friction Evaluation}

The frictional force between the pin and rotating disk during the test was measured by using a load cell attached at the side of the pin-holding lever arm and the values were recorded. The coefficient of friction was calculated simply by dividing the frictional force value with the corresponding axial load based on the Eq. (1).

$$
\mu=\frac{F}{N}
$$

where $\mu$ is coefficient of friction, $F$ is friction force and $N$ is applied normal load.

Coefficient of friction would show its prominent function in the determination of transmission efficiencies through moving mating components. LVDT sensor which was directly connected to a display monitor detected the wear rate of the pin. Less resistance contributes to higher efficiency. Therefore, in terms of lubricant, less friction and wear is desirable.

\subsection{Weight Loss Evaluation}

The pins were firstly weighed using an electronic balance with an accuracy of $0.1 \mathrm{mg}$. Each pin was measured three times to obtain an average value and reduce the impact of possible measurement errors in the calculation. After the experiment, the pin was cleaned with acetone and the weights of the pin were recorded again. The difference of pin mass before and after the experiment would be used to evaluate the wear rate of the specimen.

\subsection{Surface Finish Measurement}

Before the beginning of individual test, the disk and pin surfaces were cleaned with acetone to confirm there would be no additional particles on the surfaces. The surfaces of the pin and disk were uni-directionally polished using abrasive paper to a surface roughness value, $\mathrm{Ra}$, of about $0.4 \pm 0.1 \mu \mathrm{m}$ using surface roughness profiler which included a stylus detector to determine the pattern of the disk and pin surfaces. The surface finish after experiment once again was measured to analyze the influence of the lubricant used during the experiment. After the experiment, the picture of the pin surface that made a direct contact with the disk was captured with a CCD camera for observation.

\subsection{RESULTS}

\subsection{Viscosity}

Before the experiment was conducted, a specific density and dynamic viscosity of the three lubricants; RBD palm olein (PO), commercial hydraulic oil (HO) and additive-free paraffinic mineral oil (PMO) had been measured in order to analyze the effect of temperature on the dynamic viscosity of lubricating oil. Dynamic viscosity is defined as the fluid resistance to shear or flow and is an amount of frictional fluid property. The fluidity of viscosity was changed at different temperatures. ISO 8217 was selected as a reference for the experiment and the reference temperature for a residual fluid was $100^{\circ} \mathrm{C}$ while for a distillate fluid, the reference temperature was $40^{\circ} \mathrm{C}$. A laboratory experiment was carried out by following a standard procedure to measure the density of the lubricant while a viscometer was used to measure the dynamic viscosity of lubricants. From the result, it showed that the fluidity of three types of lubricant decreased as the temperature increased. The fluidity of lubricants decreased resulting from the declined intermolecular force within the lubricants. The additional vibration between atoms broke down the inter-molecular forces and adhesion between molecules. The specific density and dynamic viscosity of RBD palm olein, commercial hydraulic oil and additive-free paraffinic mineral oil are shown in Table 1.

Table 1 Viscosity of RBD palm olein, hydraulic oil and paraffinic mineral oil

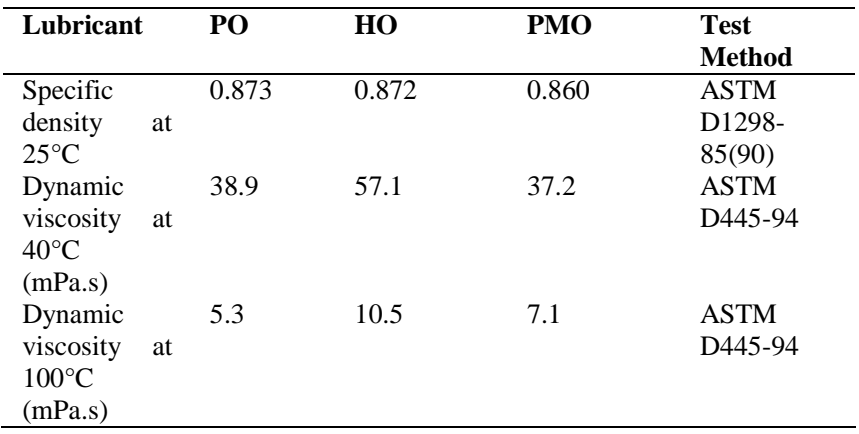

\subsection{Coefficient Of Friction}

To study the anti-friction behavior of palm oil, several experiments were conducted using different loads, which were $4.96 \mathrm{~N}$ and $19.68 \mathrm{~N}$ with $0.5 \mathrm{~m} / \mathrm{s}$ of sliding speed. The duration of the experiment was one hour (3600 seconds). The anti-friction behavior of RBD palm olein (PO) was compared with the antifriction behavior of commercial hydraulic oil (HO) and additivefree paraffinic mineral oil (PMO). Frictional force obtained directly from the experiment using LVDT sensor was converted into the friction coefficient value according to Eq. 1. The relation between coefficient of friction and time is illustrated in Figure 2.

From Figure 2, it clearly seen that friction coefficient obtained with lubrication of RBD palm olein gives the lowest value. At the early stage of sliding time (600s), the friction coefficient increased around 0.08 , then decreased to 0.05 and subsequently created a stable friction coefficient until the completion of experiment. RBD palm olein showed a better characteristic of lubrication due to the large difference than the friction coefficient with lubrication of paraffinic mineral oil and hydraulic oil. Paraffinic mineral oil exhibited an upgoing curve from the beginning of the experiment to a friction coefficient around 0.30 at the end of experiment while the hydraulic oil had a high value of friction coefficient about 0.40 at the beginning of 600 s and kept decreasing constantly to a value of 0.33 after the completion of the experiment.

At high normal load applied, 19.68N, (Figure 2 with grey marks), all test lubricants showed increment of coefficient of friction, compared with the results of low normal load $(4.96 \mathrm{~N})$. The coefficient of friction for the specimen with lubrication of palm oil showed the lowest value compared to paraffinic mineral oil and hydraulic oil. In contrast with low load applied, at high applied load, the friction coefficients obtained approximately showed a similar trend which created a stable value from the beginning till the completion of experiment. The experiment 
conducted with lubrication of palm oil produced a friction coefficient value of 0.40 and fluctuated with 0.02 in range, almost maintaining a stable value and ended with value of 0.42 at the completion of experiment. The friction coefficient with lubrication of hydraulic oil and paraffinic mineral oil had approximately similar values, around 0.46 throughout the experiments.

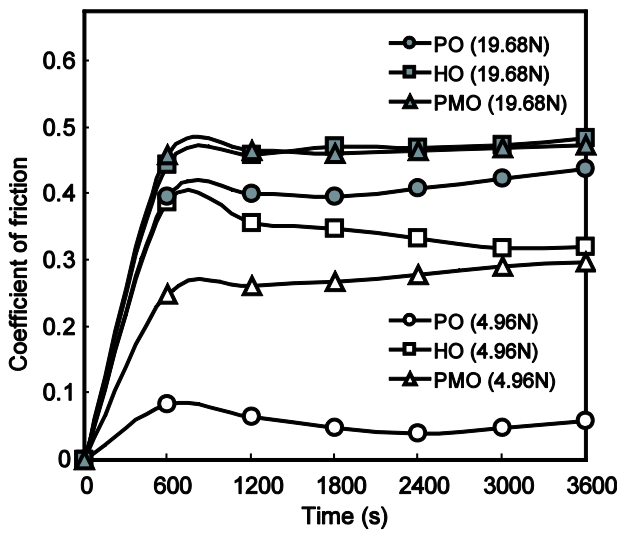

Figure 2 Coefficient of friction at load $4.96 \mathrm{~N}$ and $19.68 \mathrm{~N}$

\subsection{Worn Condition of the Pin}

During the experiment, LVDT sensor was used to measure the distance of pin that moved toward the disk. The more distance shown by the LVDT means that more material of the pin was worn by the disk. The increment of the worn distance relative to the time was plotted as Figure 3(a) and (b), for normal load 4.96N and $19.68 \mathrm{~N}$ respectively.

For lower normal load $(4.96 \mathrm{~N})$, it was found that the wear for the pin lubricated with RBD palm olein was the lowest compared to paraffinic mineral oil. The wear rate for the pin lubricated with hydraulic oil was almost similar with those lubricated with RBD palm olein at high normal load applied to the pin $(19.68 \mathrm{~N})$, hence it is a comparison of data presented in Figure 4. The curves indicate that wear values obtained for the pin lubricated with RBD palm olein was significantly the highest value compared to paraffinic mineral oil and hydraulic oil.

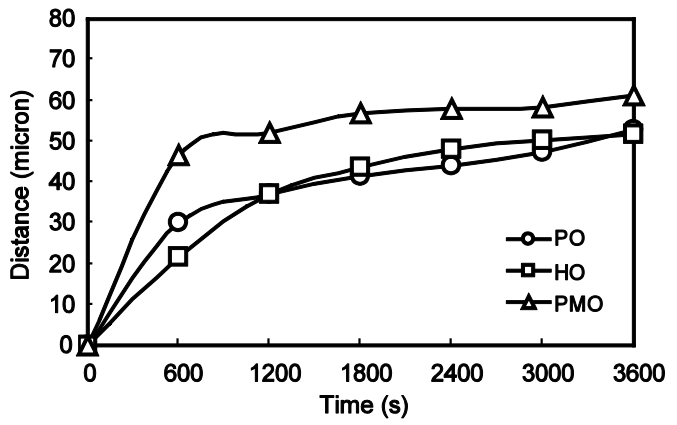

(a)

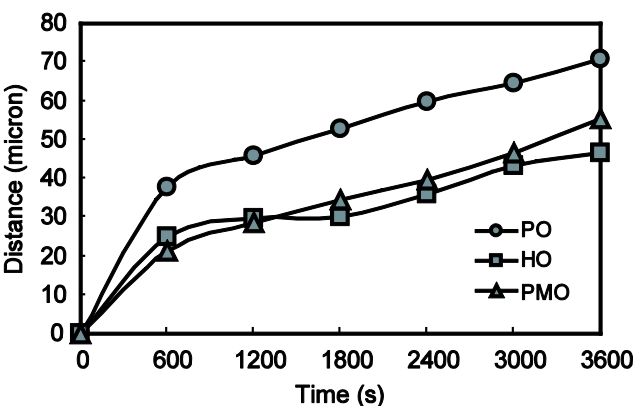

(b)

Figure 3 Worn condition of the pin for normal load (a) $4.96 \mathrm{~N}$ and (b) $19.68 \mathrm{~N}$

\subsection{Weight Loss of the Pin}

The pin was weighed before and after the experiment to know the difference of pin mass loss after the experiment. The results are shown in Figure 4. By using the weight loss data, the wear rate relative to the sliding distance was calculated using Eq. (2), and the results are shown in Figure 5.

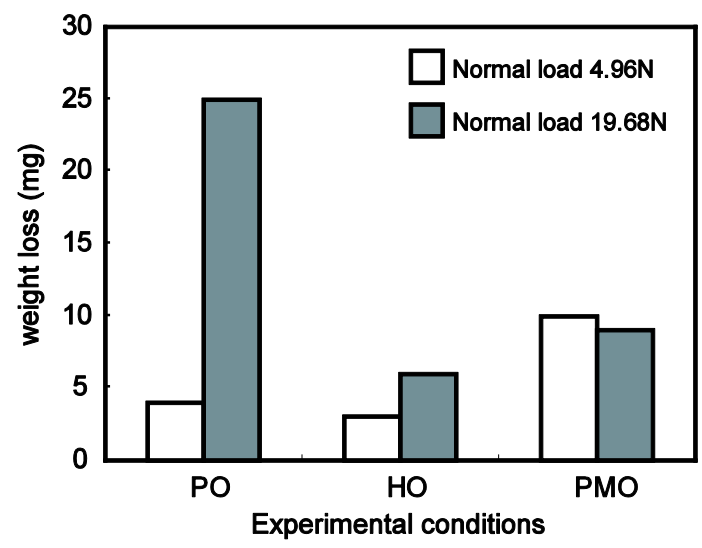

Figure 4 Weight loss of the pin for all the experimental conditions

Wear rate, $\mathrm{Q}\left(\mathrm{mm}^{3} / \mathrm{m}\right)=\frac{\Delta V}{s}$

where $\mathrm{Q}$ is the wear rate, $\Delta V$ is volume loss and $s$ is sliding distance.

From Figure 5, at normal load $(4.96 \mathrm{~N})$, it can be seen clearly that RBD palm olein and hydraulic oil give the lowest value of wear rate compared to those lubricated with paraffinic mineral oil. At high normal load $(19.68 \mathrm{~N})$, for RBD palm olein, the results obtained were shown as a reversed pattern, which the wear rate for RBD palm olein was the highest compared to hydraulic oil and paraffinic mineral oil. For hydraulic oil and paraffinic mineral oil, the addition of the normal load showed no significant increment in wear rate. 


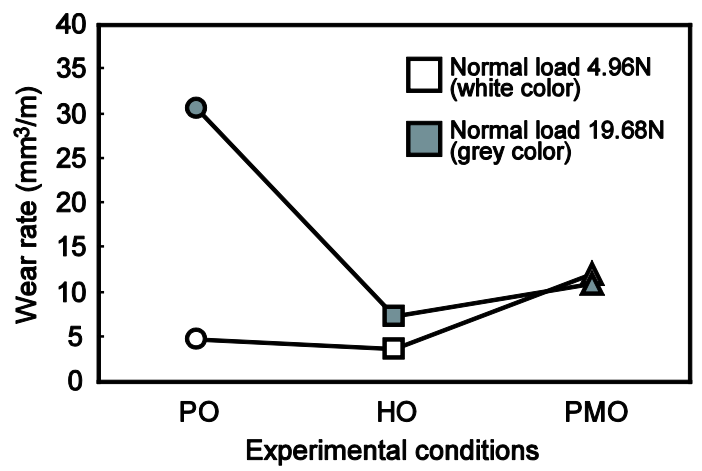

Figure 5 Wear rate for all the experimental conditions

\subsection{Surface Roughness of the Pin and Disk}

Surface roughness is one of the most essential parameters in determining the wear rate and friction coefficient and it helps to summarize the behavior of lubrication effect during the sliding time of mating components. The average values of the arithmetic surface roughness $\mathrm{Ra}$ of the experimental surface of the pin and disk were measured and shown in Figure 6 and 7 for all experimental conditions. The surface roughness Ra for pin and disk were set at $0.4 \pm 0.1 \mu \mathrm{m}$ before the experiment.

For the normal load of $4.96 \mathrm{~N}$, for RBD palm olein and hydraulic oil, the surface roughness of the pin slightly increased compared to the $\mathrm{Ra}$ value before the experiment. For the paraffinic mineral oil, the Ra value increment was the highest. For the normal load of $19.68 \mathrm{~N}$, the Ra value for the pin lubricated with RBD palm olein became the highest, followed by paraffinic mineral oil and hydraulic oil.

After the experiment, the surface roughness Ra for the disk increased for all the experimental conditions compared to the $\mathrm{Ra}$ value before the experiment. However, the worn conditions of the disk were almost similar for all test lubricants.

Micrographs of the worn surface of the pin produced after one hour (3600 seconds) tests lubricated with RBD palm olein, hydraulic oil and paraffinic mineral oil were observed using CCD camera. The surface conditions were captured as shown in Figure 8.

At low normal load $(4.96 \mathrm{~N})$ applied, the surface lubricated with RBD palm olein (Figure 8(a)) and hydraulic oil (Figure 8(b)) showed smooth surfaces due to the thin lubricant layer formed and was enough to preserve metal to metal contact of rubbing surfaces. At high load, the surfaces seemed to be rougher due to the reduction of the thin film affected by the increased temperature of lubricant resulting in high wear. It is believed that the particles of the pin was transferred and embedded onto the disk surface.

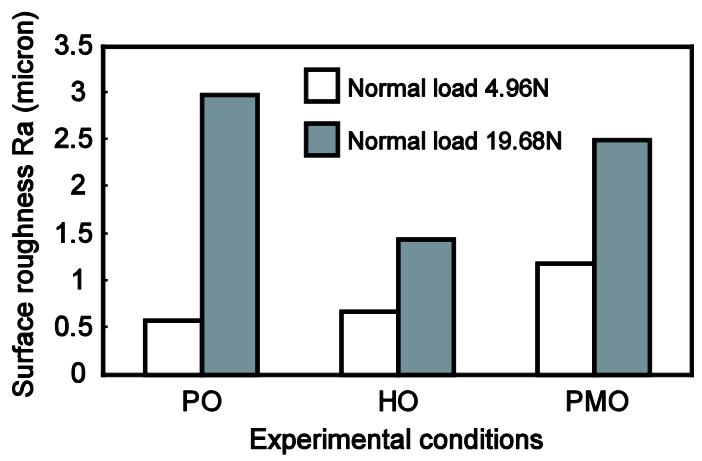

Figure 6 Surface roughness, Ra for the pin surface

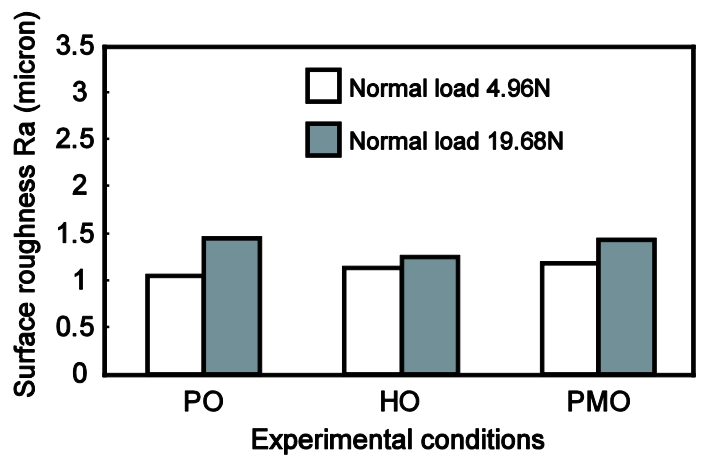

Figure 7 Surface roughness, Ra for the disk surface

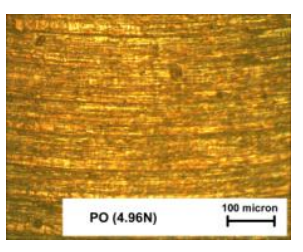

(a)

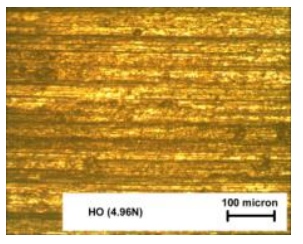

(b)

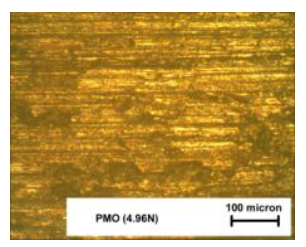

(c)

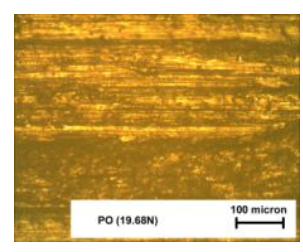

(d)

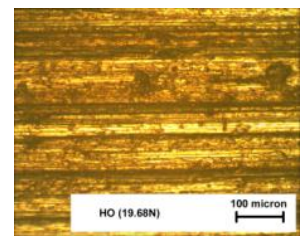

(e)

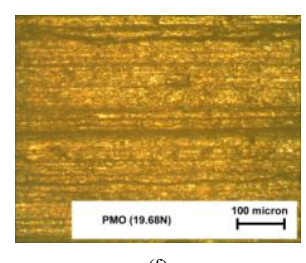

(f)
Figure $8 \mathrm{CCD}$ micrograph of worn surface for all the experimental conditions

\subsection{DISCUSSION}

In this experiment, the tribological performance RBD palm olein (written as PO) was evaluated using pin-on-disk tribotester. The same comparative experiments and analysis were done using commercial hydraulic oil (written as $\mathrm{HO}$ ) and additive-free paraffinic mineral oil (written as PMO) for comparison with the results obtained by RBD palm olein.

For both normal load conditions, which were $4.96 \mathrm{~N}$ and $19.68 \mathrm{~N}$, the experiment with lubrication of RBD palm olein showed a better result compared to the commercial hydraulic oil and additive-free paraffinic mineral oil. Friction coefficient obtained from those lubricated with RBD palm olein gave the lowest result for both low and high normal loads. It could be assumed that the fatty acid in RBD palm olein resulted in a significant improvement of the friction. It is believed that the two contacted surface would create a metal oxide layer and would react with the fatty acid of palm oil, creating a thin layer of lubricant. Syahrullail et al. (2011) explained that this reduced the metal-to-metal contact and thus reduced the friction coefficient resulted in the experiment. Yunus et al. (2004) added that palm oil 
is mainly composed of unsaturated fatty acid, triglycerides, and non-glycerides substance. The high amount of unsaturated fatty acids in the palm oil will create high strength lubricant film and act as a boundary lubricant that will interact directly with the contacted surfaces, subsequently reducing the friction resulted. This is attributed to the fact that the molecular weight of palm oil is more consistent than that of mineral oil. It is believed that the unsaturated fatty acid in palm oil contains thicker molecular layers, which will subsequently prevent direct metal to metal contact and reduce friction, as described by Masjuki et al. (1999). At low load applied, it was observed that the friction coefficient obtained from the lubrication with palm oil and hydraulic oil created high friction coefficient at the beginning of the experiment, and then decreased as the test continued. This phenomenon happened as at the beginning of the experiment, the lubricating oil created inadequate and unstable film, thus failed to fully preserve the direct contact of mating metals. As the test continued, Temel and Zeki (2008) found that the oil film became more stable and was thick enough to prevent direct metal to metal contact, thus the friction coefficient decreased.

As the applied load increased, the friction coefficient obtained also increased. This has been confirmed by Husnawan $e t$ al. (2007) and Maleque et al. (2000) that the frictional force is directly proportional to the applied load. It can be assumed that this phenomenon took place in the boundary lubrication regime. As the applied load increased, the pressure would increase in the contact zone, thus the temperature of the lubricating oil would increase as well, as explained by Temel and Zeki (2008). From the beginning of the experiment, it was observed that the viscosity was inversely proportional to the temperature of lubricating oil. As reported by Ching-Fang and Tomlinson (2004), as referred to the stribeck curve, the stribeck curve is the function of viscosity, speed and load. As the load applied is increased and the viscosity is decreased, where sliding speed is fixed, it has been proven that the friction coefficient will increase as well.

Wear is a comparatively uniform phenomenon as shown in Figure 5. There are correlations between the wear obtained directly using LVDT sensor with the weight loss recorded, wear rate and specific wear rate calculated. At low load, the wear obtained with lubrication of RBD palm olein showed the lowest value. Masjuki and Maleque (1996) and Sharma et al. (2008) found that the palm oil had the ability to form a thin film by chemical adsorption of fatty acid onto the interface. This phenomenon is called soap film, where it reduces direct metal to metal contact and avoids severe wear. In contrast, at high load, a surprising finding was observed. The highest wear was obtained from the lubrication of RBD palm olein due to the high load, therefore increased the temperature of the lubricant. The viscosity of palm oil also decreased as the test continued, attributed to the reduction of protective film, resulting in the breakdown of boundary lubrication. Another explanation is due to the rise of lubricating oil temperature, causing the lack of the stability of the molecular layer created by unsaturated free fatty acids and thereby caused comparatively higher wear (Masjuki et al., 1999) and metal oxide layer or soap film formed by fatty acid, which became thinner and insufficient to preserve metal to metal contact, thus attributed to the increment of wear resistance.

Surface roughness is another parameter that can influence the wear resistance and friction of mating components. Normally, the surface with low surface roughness, Ra, value has shallow asperities and conversely, the surface with high surface roughness, Ra, value has deep asperities. The existence of deep asperities can help lubricants to maintain in supplying lubricant along the process. At low normal load, RBD palm olein showed low coefficient of friction due to the fatty acid that stuck on the material surface. However, at high normal load, the deep asperities created a lubricant reservoir that continued supplying the lubricant. As a result, the coefficient of friction for RBD palm olein was the lowest compared to hydraulic oil and paraffinic mineral oil. For hydraulic and paraffinic mineral oil, at high normal load, the Ra values increased, meaning that deep asperities were constructed, but the absence of fatty acid made hydraulic and paraffinic mineral oil lubricant films broke down due to high pressure, as explained by Williams (2005) and Tiong et al. (2012).

The roughness of the surfaces or random texture is attributed to the amount of lubricating oil retention on the random texture, thus reducing the friction. Pradeep et al. (2008) suggested that the wear particles of titanium pin might get locked between the sliding surfaces or transferred and embedded to the mated disks, subsequently giving many damages to the pin. This then, had led to the adhesive action and promoted three bodies which should enhance the volume loss in wear. Meanwhile, at the low load, the fatty acids of palm oil stuck very well onto the pin and disk surface and created a thin layer to preserve the surface, therefore resulting in good surface finishing and low wear resistance and friction. Overall observation saw that there were no severe adhesion wears occurring on both pin and disk surface for all test lubricant conditions.

The result of the coefficient of friction for commercial hydraulic oil showed some similarities with the additive-free paraffinic mineral oil as shown in Figure 2. However, the hydraulic oil showed an excellent wear resistance at both low and high load as shown in Figure 5 and 6. It was due to the additive contained in the hydraulic oil.

\subsection{CONCLUSION}

The tribological behavior of RBD palm olein had been evaluated using the pin-on-disk tribotester. All the results of RBD palm olein were compared mutually with the results of the commercial hydraulic oil and additive-free paraffinic mineral oil. The experimental and analytical results can be summarized as follow:

(1) The friction coefficient obtained from those lubricated with RBD palm olein was the lowest compared to those lubricated with hydraulic oil and paraffinic mineral oil, for both low and high normal load conditions. The friction coefficient for all three lubricating oils increased as the applied load was added.

(2) The wear resulted from those lubricated with RBD palm olein showed a better result at the low normal load. In contrast, at the high normal load, the wear dominated by those lubricated with RBD palm olein was high compared to hydraulic oil and paraffinic mineral oil.

\section{Acknowledgement}

The authors wish to thank the Faculty of Mechanical Engineering at the Universiti Teknologi Malaysia for their support and cooperation during this study. The authors also wish to thank Research Management Centre (RMC) for the Research University Grant (GUP) from the Universiti Teknologi Malaysia, Fundamental Research Grant Scheme (FRGS) from the Ministry of Higher Education (MOHE) and E-Science Grant and ERGS from the Ministry of Science, Technology and Innovation (MOSTI) of Malaysia for their financial support. 


\section{References}

[1] Bowden, F. P., Tabor, D. 2001. The Nature of Metallic Wear. The Friction and Lubrication of Solids. Oxford University Press, UK.

[2] Bressan, J. D., Daros, D. P., Sokolowski, A., Mesquita, R. A., Barbosa, C. A. 2008. Influence of Hardness on the Wear Resistance of 17-4 PH Stainless Steel Evaluated By The Pin-on-disk Testing. Journal of Materials Processing Technology. 205: 353-359.

[3] Ching-Fang, T. U., Tomlinson, F. 2004. A Study of Fiber-capstan Friction. 1. Stribeck Curves. Tribology International. 37: 701-710.

[4] Chowdhury, M. A., Khalil, M. K., Nuruzzaman, D. M., Rahaman, M. L., 2011. The Effect of Sliding Speed and Normal Load on Friction and Wear Property of Aluminum. International Journal of Mechanical \& Mechatronics Engineering. 11: 53-57.

[5] Delgado, M. A., Quinchia, L. A., Galegos, C. 2010. Viscosity modification of Different Vegetable Oil with EVA Copolymer for Lubricant Applicants. Industrial Crops and Products. 32: 607-612.

[6] Garcia-Prieto, I., Faulkner, M. D., Alcock, J. R. 2004. The influence of Specimen Misalignment on Wear in Conforming Pin on Disk Tests. Wear. 257: 157-166.

[7] Husnawan, M., Saifullah, M. G., Masjuki, H. H. 2007. Development of Friction Force Model for Mineral Oil Base Stock Containing Palm Oil and Antiwear Additive. Tribology International. 40: 74-81.

[8] Lawal, S. A., Choudhury, I. A., Nukman, Y. 2012. Application of Vegetable Oil Based Metal Working Fluids in Machining Ferrous Metals-A Review. International Journal of Machine Tools \& Manufacture. 52: 1-12.

[9] Maleque, M. A., Masjuki, H. H., Haseeb, A. S. M. A. 2000. Effect of Mechanical Factors on Tribological Properties of Palm Oil Methyl Ester Blended Lubricant. Wear. 239: 117-25.

[10] Masjuski, H. H., Maleque, M. A. 1996. The Effect of Palm Oil Diesel Fuel Contaminated Lubricant on Sliding Wear of Cast Irons Against Mild Steel. Wear. 198: 293-299.

[11] Masjuki, M. M., Maleque, M. A., Kubo, A., Nonaka, T. 1999. Palm Oil and Mineral Oil Based Lubricants-Their Tribological and Emission Performance. Tribology International. 32: 305-314.

[12] Mekhilef, S., Siga, S., Saidur, R. 2011. A Review on Palm Oil Biodiesel as a Source of Renewable Fuel. Renewable and Sustainable Energy Reviews. 15: 1937-1949.

[13] Nofal,. A., Hussein, S. 2011. Effect of Temperature on Sliding Wear Mechanism under Lubrication Conditions, International Journal of Engineering. 5: 176-184.
[14] Nosonovsky, M. 2007. Oil as a Lubricant in the Ancient Middle East, Tribology Online 2(2): 44-47.

[15] Pascal, N., Mohand, T. 2011. Use of Palm oil-based biofuel in the Internal Combustion Engines: Performance and Emissions Characteristics. Energy. 36: 1790-1796.

[16] Pradeep, L. M., Kishore, Satish, V. K. 2008. Effect of Surface Roughness Parameters and Surface Texture on Friction and Transfer Layer Formation in Tin-steel tribo-system. Journal of Materials Processing Technology. 208: 372-382.

[17] Sedlacek, M., Podgornik, B., Vizintin, J. 2009. Influence of Surface Preparation on Roughness Parameters, Friction and Wear. Wear. 266: $482-487$.

[18] Sharma, B. K., Doll, K. M., Erhan, S. Z. 2008. Ester Hydroxyl Derivatives of Methyl Oleate: Tribological, Oxidation and Low Temperature Properties. Bioresourse Technology. 99: 7333-7340.

[19] Syahrullail, S., Zubil, B. M., Azwadi, C. S. N., Ridzuan, M. J. M. 2011 Experimental Evaluation of Palm Oil as Lubricant in Cold Forward Extrusion. International Journal of Mechanical Sciences. 53: 549-555.

[20] Temel, S., Zeki, A. 2008. An Investigation of Lubricated Friction and Wear Properties of $\mathrm{Zn}-40 \mathrm{Al}-2 \mathrm{Cu}-2 \mathrm{Si}$ Alloy in Comparison with SAE 65 Bearing Bronze. Wear. 264: 920-928.

[21] Terumasa, H., Kentarou, M., Akiyoshi, K., Satoru, N. 2000. Effects of Surface Roughness of Roll Metal Pins on Their Friction and Wear Characteristics. Wear. 239: 69-76.

[22] Tiong, C. I., Mohammed Rafiq, A. K., Azli, Y. and Syahrullail, S. 2012 The Effect of Temperature on the Tribological Behavior of RBD Palm Stearin. Tribology Transactions. 55(5): 539-548.

[23] Wan Nik, W. B., Ani, F. N., Masjuki, H. H., and Giap, S. G. E. 2005 Rheology of Bio-edible Oils According to Several Rheological Models and Its Potential as Hydraulic Fluid. Industrial Crops and Products. 22: 249-255.

[24] Williams, J. 2005. Engineering Tribology. Cambridge University Press, UK

[25] Yunus, R., Razi, A. F., Ooi, T. L., Iyuke, S. E., Perez, J. M. 2004. Lubrication Properties of Trimethylolpropane Esters Based on Palm Oil and Palm Kernel Oils. Eur J Lipid Sci Technol. 106: 52-60. 